NASA/TM-2012-217645

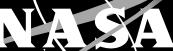

Embrittlement of MISSE 5 Polymers After 13 Months of Space Exposure

Aobo Guo, Grace T. Yi, Claire C. Ashmead, and Gianna G. Mitchell Hathaway Brown School, Shaker Heights, Ohio

Kim K. de Groh

Glenn Research Center, Cleveland, Ohio

Bruce A. Banks

Alphaport, Inc., Cleveland, Ohio 


\section{NASA STI Program . . . in Profile}

Since its founding, NASA has been dedicated to the advancement of aeronautics and space science. The NASA Scientific and Technical Information (STI) program plays a key part in helping NASA maintain this important role.

The NASA STI Program operates under the auspices of the Agency Chief Information Officer. It collects, organizes, provides for archiving, and disseminates NASA's STI. The NASA STI program provides access to the NASA Aeronautics and Space Database and its public interface, the NASA Technical Reports Server, thus providing one of the largest collections of aeronautical and space science STI in the world. Results are published in both non-NASA channels and by NASA in the NASA STI Report Series, which includes the following report types:

- TECHNICAL PUBLICATION. Reports of completed research or a major significant phase of research that present the results of NASA programs and include extensive data or theoretical analysis. Includes compilations of significant scientific and technical data and information deemed to be of continuing reference value. NASA counterpart of peer-reviewed formal professional papers but has less stringent limitations on manuscript length and extent of graphic presentations.

- TECHNICAL MEMORANDUM. Scientific and technical findings that are preliminary or of specialized interest, e.g., quick release reports, working papers, and bibliographies that contain minimal annotation. Does not contain extensive analysis.

- CONTRACTOR REPORT. Scientific and technical findings by NASA-sponsored contractors and grantees.
- CONFERENCE PUBLICATION. Collected papers from scientific and technical conferences, symposia, seminars, or other meetings sponsored or cosponsored by NASA.

- SPECIAL PUBLICATION. Scientific, technical, or historical information from NASA programs, projects, and missions, often concerned with subjects having substantial public interest.

- TECHNICAL TRANSLATION. Englishlanguage translations of foreign scientific and technical material pertinent to NASA's mission.

Specialized services also include creating custom thesauri, building customized databases, organizing and publishing research results.

For more information about the NASA STI program, see the following:

- Access the NASA STI program home page at http://www.sti.nasa.gov

- E-mail your question to help@sti.nasa.gov

- Fax your question to the NASA STI Information Desk at 443-757-5803

- Phone the NASA STI Information Desk at 443-757-5802

- Write to: STI Information Desk NASA Center for AeroSpace Information 7115 Standard Drive Hanover, MD 21076-1320 
NASA/TM-2012-217645

.

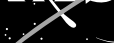

Embrittlement of MISSE 5 Polymers After 13 Months of Space Exposure

Aobo Guo, Grace T. Yi, Claire C. Ashmead, and Gianna G. Mitchell

Hathaway Brown School, Shaker Heights, Ohio

Kim K. de Groh

Glenn Research Center, Cleveland, Ohio

Bruce A. Banks

Alphaport, Inc., Cleveland, Ohio

Prepared for the

10th International Space Conference on Protection of Materials and Structures From

the Space Environment (ICPMSE-10J)

cosponsored by ITL, MDA, CSA, JAXA, Kobe University Graduate School of Engineering, and the Society for Promotion of Space Science

Bankoku-Shinryokan, Okinawa, Japan, June 12-17, 2011

National Aeronautics and

Space Administration

Glenn Research Center

Cleveland, Ohio 44135 


\section{Acknowledgments}

We would like to express our sincere appreciation to Bill Kinard, formerly of NASA Langley Research Center, and Gary H. Pippin, formerly of Boeing, for providing the unique opportunity to be a part of the MISSE 5 Thermal Blanket Materials Experiment. We also thank Patty Hunt of Hathaway Brown School for making it possible for the students to be a part of this project. This work was support by the NASA ISS Research Program.

Trade names and trademarks are used in this report for identification only. Their usage does not constitute an official endorsement, either expressed or implied, by the National Aeronautics and Space Administration.

Level of Review: This material has been technically reviewed by technical management.

Available from

NASA Center for Aerospace Information 7115 Standard Drive

Hanover, MD 21076-1320
National Technical Information Service 5301 Shawnee Road Alexandria, VA 22312

Available electronically at http://www.sti.nasa.gov 


\title{
Embrittlement of MISSE 5 Polymers After 13 Months of Space Exposure
}

\author{
Aobo Guo, Grace T. Yi, Claire C. Ashmead, and Gianna G. Mitchell \\ Hathaway Brown School \\ Shaker Heights, Ohio 44122 \\ Kim K. de Groh \\ National Aeronautics and Space Administration \\ Glenn Research Center \\ Cleveland, Ohio 44135 \\ Bruce A. Banks \\ Alphaport, Inc. \\ Cleveland, Ohio 44135
}

\begin{abstract}
Understanding space environment induced degradation of spacecraft materials is essential when designing durable and stable spacecraft components. As a result of space radiation, debris impacts, atomic oxygen interaction, and thermal cycling, the outer surfaces of space materials degrade when exposed to low Earth orbit (LEO). The objective of this study was to measure the embrittlement of 37 thin film polymers after LEO space exposure. The polymers were flown aboard the International Space Station and exposed to the LEO space environment as part of the Materials International Space Station Experiment 5 (MISSE 5). The samples were flown in a nadir-facing position for 13 months and were exposed to thermal cycling along with low doses of atomic oxygen, direct solar radiation and omni-directional charged particle radiation. The samples were analyzed for space-induced embrittlement using a bend-test procedure in which the strain necessary to induce surface cracking was determined. Bend-testing was conducted using successively smaller mandrels to apply a surface strain to samples placed on a semisuspended pliable platform. A pristine sample was also tested for each flight sample. Eighteen of the 37 flight samples experienced some degree of surface cracking during bend-testing, while none of the pristine samples experienced any degree of cracking. The results indicate that 49 percent of the MISSE 5 thin film polymers became embrittled in the space environment even though they were exposed to low doses ( $2.75 \mathrm{krad}(\mathrm{Si})$ dose through $127 \mu \mathrm{m}$ Kapton) of ionizing radiation.
\end{abstract}

\section{Introduction}

As a result of space radiation, debris impacts, atomic oxygen interaction, and thermal cycling, the outer surfaces of space materials degrade when exposed to low Earth orbit (LEO) (Ref. 1). As ionizing radiation is known to embrittle polymers and has severely embrittled the Teflon fluorinated ethylene propylene (FEP) outer layer of the multilayer insulation covering the Hubble Space Telescope (Ref. 2). A study was conducted to measure the embrittlement of 37 thin film polymers after LEO space exposure. The polymers were flown aboard the International Space Station and exposed to the LEO space environment for 13 months as part of the Materials International Space Station Experiment 5 (MISSE 5). 
MISSE is a series of spaceflight experiments designed to test the performance and durability of materials and devices exposed to the low Earth orbit (LEO) space environment. MISSE consists of 11 flight experiment trays (10 Passive Experiment Carriers (PECs) and one smaller tray being flown with MISSE 8) that are mounted to the exterior of the International Space Station (ISS). Each two-sided tray contains numerous individual flight experiments and are positioned in either a ram/wake orientation or a zenith/nadir orientation (Ref. 3). The MISSE 5 polymer samples were from the Polymer Erosion and Contamination Experiment (PEACE) and were flown in a nadir-facing position for 13 months, which resulted in exposure to omni-directional charged particle radiation, thermal cycling, and low doses of atomic oxygen and direct solar radiation (Ref. 3). The samples were analyzed for space-induced embrittlement using a bend-test procedure in which the strain necessary to induce surface cracking was determined. Details on the MISSE 5 experiment, polymer flight samples, test procedures, and bend-test results are provided.

\section{MISSE 5 Experiments and Exposure}

MISSE 5 contained two active and one passive experiments: The Forward Technology Solar Cell Experiment (FTSCE), an active experiment that tested the performance of 36 current and advanced generation solar cells for use on future spacecraft; the active Second Prototype Communication Satellite System (PCSat-2) that provided a communications system and tested the Amateur Satellite Service off-the-shelf solution for telemetry command and control; and the passive MISSE 5 Thermal Blanket Materials Experiment, which consisted of several individual experiments to measure the degradation of more than 200 materials in the space environment (Ref. 3). The 37 PEACE samples were flown as part of the MISSE 5 Thermal Blanket Materials Experiment.

MISSE 5 was placed in a zenith/nadir position on the P6 Trunion Pin Handrail of the International Space Station (ISS) during the STS-1 14 mission on August 3, 2005. Figure 1 shows a pre-flight photograph of MISSE 5 and an on-orbit photo taken during the STS-114 mission. MISSE 5 was exposed to the LEO space environment for 13 months, and was retrieved on September 15, 2006 during the STS-115 mission.

It is estimated that the polymers received an ionizing radiation (also called charged particle radiation) dose of $\sim 2.75 \mathrm{krads}(\mathrm{Si})$ through $127 \mu \mathrm{m}$ Kapton, 165 \pm 25 direct Sun hours ( $\sim 360$ Earth reflected), an atomic oxygen fluence of $\sim 1.8 \times 0.10^{20}$ atoms $/ \mathrm{cm}^{2}$, and 6400 thermal cycles (Ref. 4). Temperature range was estimated from the experiment deck temperature for the Forward Technology Solar Cell Experiment on the solar facing side of MISSE 5 (Ref. 5).

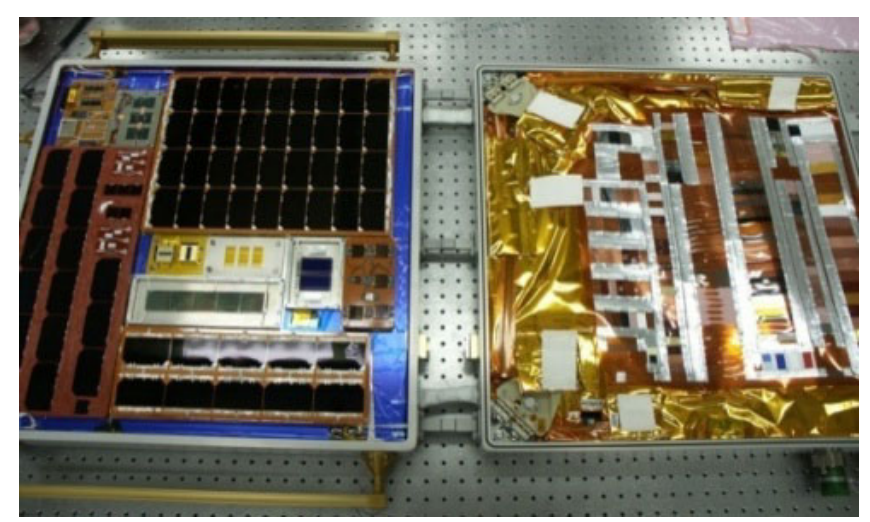

(a)

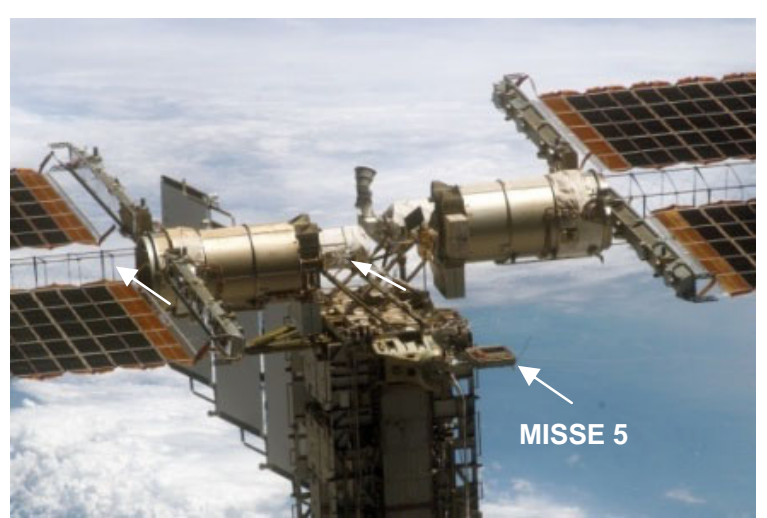

(b)

Figure 1.-MISSE 5: (a) Pre-flight, and (b) On-orbit photo taken during STS-114 of the zenith facing experiments. 


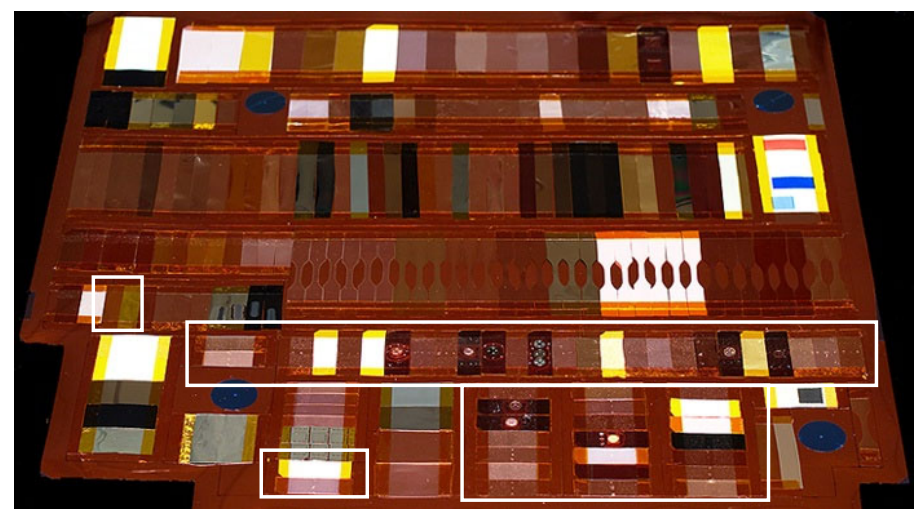

Figure 2.-Pre-flight photograph of the MISSE 5 Thermal Blanket Experiment (before the stitching and additional tape was applied). The PEACE Polymer samples are outlined in white.

\section{MISSE 5 PEACE Polymers Experiment}

The MISSE 5 PEACE Polymers experiment consisted of 49 to 0.5 in. $(1.27 \mathrm{~cm}) \times 1.5$ in. $(3.81 \mathrm{~cm})$ rectangular polymer material samples with 53 polymer materials. The majority of samples were thin film flexible polymers. A few rigid samples were also flown sandwiched between two pieces of either Kapton H or Kapton HN with Y966 acrylic adhesive. The primary experiment objective was to determine the atomic oxygen erosion yield (Ey, $\mathrm{cm}^{3} /$ atom) of polymers after space exposure in a nadir orientation. As the Thermal Blanket Materials Experiment needed to be thin and flexible, samples were taped and then sewn onto a Kapton blanket substrate therefore making determination of the Ey based on mass loss impossible. Therefore, all samples were dusted with fine salt-spray particles to provide isolated locations of protection from atomic oxygen erosion so that recession depth measurements could be made post-flight for Ey determination (Ref. 3). Figure 2 is a pre-flight photograph of the MISSE 5 Thermal Blanket Experiment with the PEACE Polymer experiment samples highlighted.

Thirty-seven of the 49 PEACE polymer samples were in a configuration that could be evaluated for surface embrittlement through bend-testing. The other 12 samples were not in thin film form and hence were not tested. A list of the flight samples that were tested along with the MISSE 5 flight sample number, the polymer name, the polymer abbreviation, trade names and the film thickness, are provided in Table 1 in the Results and Discussion section.

\section{Experiment Procedures}

\section{Sectioning Bend-Test Samples}

Because the MISSE 5 PEACE polymers were multi-purpose samples, only a portion of each sample was bend-tested for strain-induced surface cracking. A piece measuring 0.5 in. $(1.27 \mathrm{~cm}) \times 0.2$ in. $(0.508 \mathrm{~cm})$ of each sample was sectioned for bend testing. The small salt particles were removed from the samples prior to bend-testing by carefully brushing off the dust with a small horse-hair water color brush. The salt was washed off a few samples (M-2, M-18, M-24, T-1, T-6) by rinsing with water and then gently drying the sample with pressurized nitrogen.

\section{Bend-Test Procedures}

The samples were analyzed for space-induced embrittlement using a bend-test procedure in which a surface strain was applied to the sample without adding overall tensile load. The strain necessary to induce surface cracking was determined by bending the samples over mandrels. Bend-testing was conducted using an apparatus with a semi-suspended pliable platform, and a set of mandrels varying in 
diameter. A total of 23 mandrels were used, ranging in diameter from 1.253 to $0.052 \mathrm{~cm}$. The diameter of each mandrel was calculated by using the mean diameter obtained by averaging four measurements made using Fowler \& NSK Max-Cal electronic digital calipers. Each sample was bend-tested using successively smaller mandrels, with the sample being inspected after being bent around each mandrel. This procedure was continued until cracks were visible or until the sample did not experience any cracking with the smallest mandrel, in which case the sample was recorded as having not cracked.

During bend-testing, the sample was placed with its space-exposed face down onto the semi-guided apparatus. The mandrel was pushed down onto the sample, forcing the material to bend against a pliable surface that spanned two supports on the apparatus. The sample was bent in a U-shape, where the spaceexposed surface was in tension and the backside surface was under compression. As the diameter of the mandrels decreased, the tension on the space-exposed surface of the sample increased because the sample was forced to bend more tightly around the mandrel.

Optical microscopy was used to document any surface features in the bend-test area prior to testing, and the same area was examined after bending around each mandrel to identify and document any induced surface cracks. The samples were examined at magnifications of approximately $10 \mathrm{X}$ to $13.8 \mathrm{X}$ with an Olympus SMZ stereo-zoom optical microscope outfitted with a Canon digital camera. An electronic coordinate system, the Boeckeler Microcode II Digital Readout, was used to find the same test location for microscopy examination before and after bend-testing at each mandrel, always centered at a dot that had been marked on the sample so that it would always be bent in the same location. Depending on the size of the sample, nine to fifteen optical microscopy pictures of each sample were taken before bending so that the entire bend-test sample was documented. When the sample was first observed to crack during the bend test process, the mandrel, and hence the strain, were recorded and the sample was not tested further. If no cracks could be detected under the optical microscope, the sample was bend-tested again with the next smaller mandrel, and the procedure was repeated. To verify the test results, several samples were bend-tested more than once.

\section{Strain Calculations}

Equation (1) allows the percent strain $(E)$ to be calculated based on the thickness of the sample $(t)$ and the diameter of the mandrel $(d)$. This equation was derived from the bend-test configuration shown in Figure 3.

$$
E=\left(\frac{t}{d+t}\right) \times 100
$$

The percent strain for each individual material, as stated before, was determined based on the mandrel at which it initially cracked and the thickness of the sample.

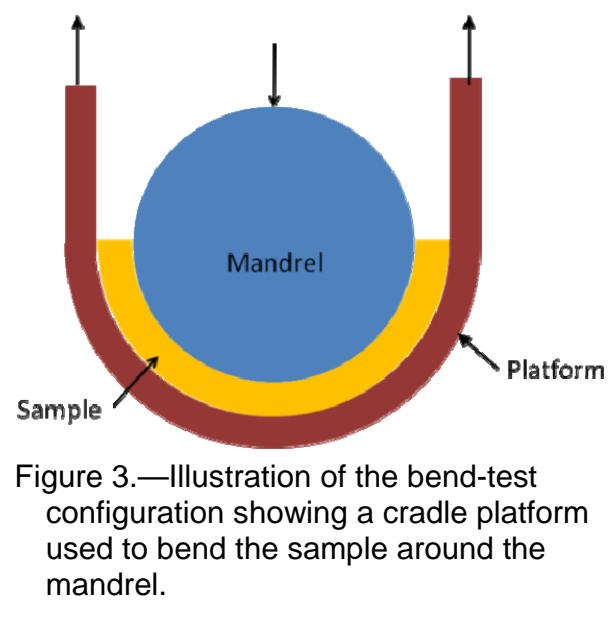




\section{Results and Discussion}

Two of the PEACE Polymers samples were found to have cracked in half while on-orbit: Sample T-1 polymethyl methacrylate (PMMA, $50.8 \mu \mathrm{m}$ thick) and Sample X-2 polymethylpentent (PMP, $50.8 \mu \mathrm{m}$ thick). Close-up post-flight photos of Samples T-1 and X-2 are shown in Figures 4(a) and (b), respectively.

The set of photos in Figure 5 is an example of the microscope images obtained before and after bendtesting with each mandrel. The sample in Figure 5 is polyvinyl fluoride (PVF), also known as clear Tedlar (MISSE T-7). The box in each figure shows where cracks developed during bend-testing. This $25.4 \mu \mathrm{m}$ thick sample cracked under a surface strain of only 0.38 percent.

While the PVF polymer shown in Figure 5 is representative of typical MISSE 5 PEACE polymer behavior, with the formulation of very small but visible vertical cracks, Figure 6 shows Sample X-2 (PMP), which exhibited more extreme behavior. This is one of two samples that cracked on-orbit. It was found to be extremely embrittled and fractured into pieces during bend-testing. In Figure 6 similar features are circled to facilitate the comparison process. Space exposure embrittled this polymer to a degree where the sample fell apart upon bend-testing with the largest mandrel (1.25 cm dia.), which provided a surface strain of only 0.4 percent. Sample T-1, PMMA, also cracked with the largest mandrel and fractured into pieces.

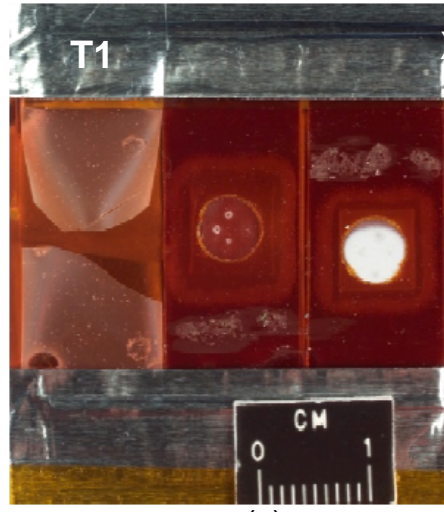

(a)

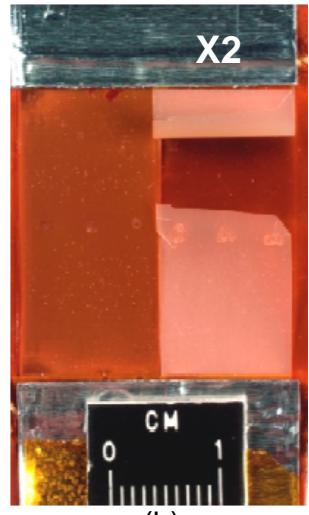

(b)

Figure 4.-Post-flight photographs of cracked PEACE samples: (a) Sample T-1, PMMA (left sample) and (b) Sample X-2, PMP (right sample).

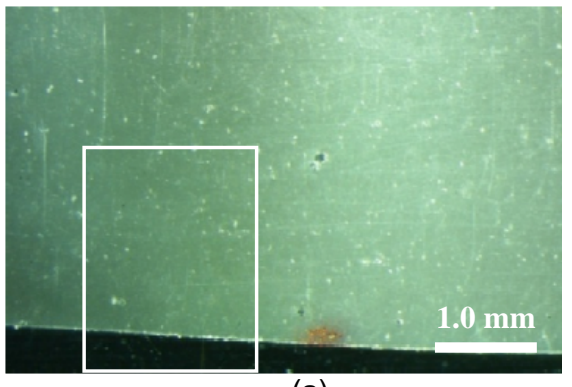

(a)

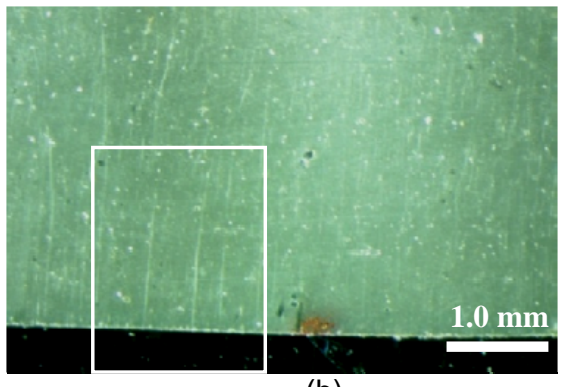

(b)

Figure 5.-Sample T-7, PVF: (a) before bend-testing and (b) after bend-testing. 


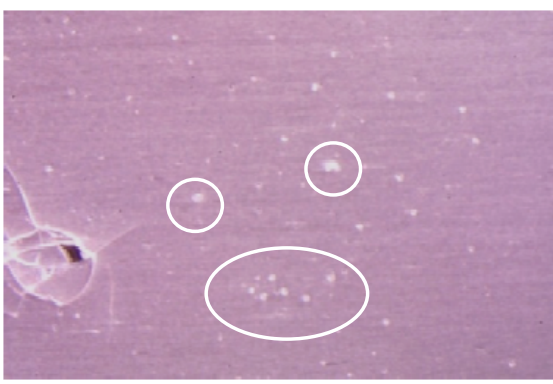

(a)

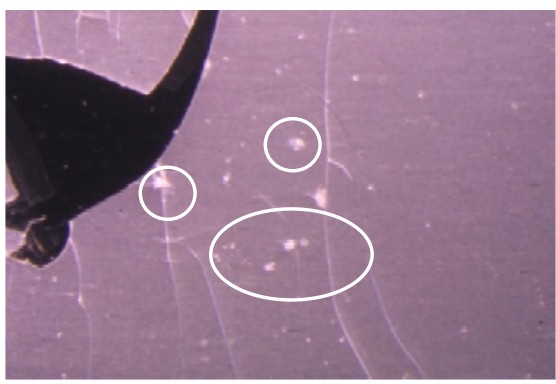

(b)

Figure 6.-Sample X-2, PMP: (a) before bend-testing and (b) after bend-testing.

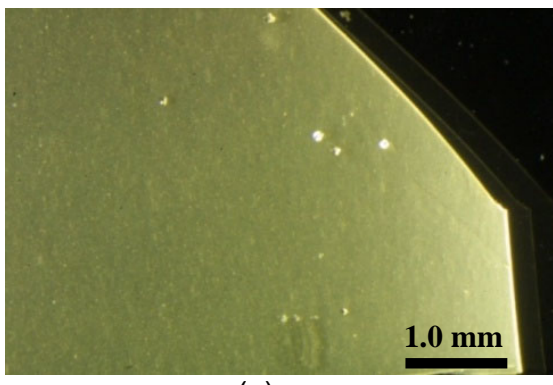

(a)

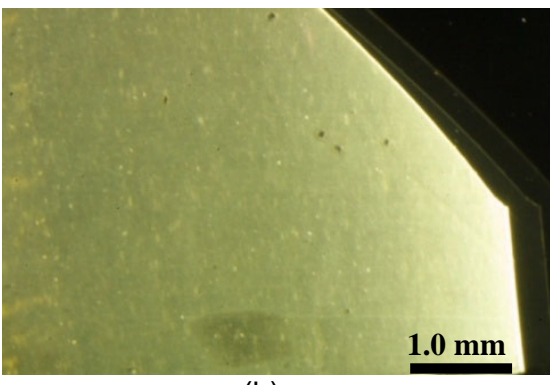

(b)

Figure 7.-Sample T-5, PU: (a) before bend-testing and (b) after bend-testing.

An example of a sample that did not crack during bend-testing, and hence remained ductile, is shown in Figure 7. This is Polyurethane (PU), MISSE 5 sample T-5. In summary, 17 of the 37 flight samples experienced some degree of surface cracking during bend-testing, while none of the pristine samples experienced any degree of surface cracking.

A list of the tested MISSE 5 PEACE samples, and their bend-test results, are provided in Table 1. In Table 1, DNC means Did Not Crack. It should also be noted that bright white materials such as Sample V-2, expanded polytetrafluoroethylene (ePTFE), would be particularly hard to see very fine surface cracks. Also, sample M-11, fluorinated ethylene propylene, appeared to contain surface scratches or cracks prior to bend testing, which may have impacted the bend-test results. Because the bend-test procedure relies on optical microscopy for identification of very small surface cracks, it is desirable to verify these bend-test results by examining the bend-tested samples with scanning electron microscopy or another technique that can verify the development of surface cracks.

The fact that surface strain induced cracking occurred in FEP (M-11), Kapton E (U-3), PTFE (V-3), and TOR (V-5), and that Upilex-S (M-14) did not crack, is consistent with results by Miller and Dever who characterized the tensile properties of these same polymers flown on the MISSE 5 Thermal Blanket Experiment as part of the Polymer Film Thermal Control Experiment (PFTC) (Ref. 4). 
TABLE 1.-MISSE 5 BEND-TESTING RESULTS

\begin{tabular}{|c|c|c|c|}
\hline $\begin{array}{l}\text { MISSE } \\
\text { ID }\end{array}$ & Material & $\begin{array}{l}\text { Thickness, } \\
\mu \mathrm{m}\end{array}$ & $\begin{array}{c}\text { Percent } \\
\text { strain }\end{array}$ \\
\hline M-02 & Cellulose acetate (CA), Clarifoil & 50.8 & $\mathrm{DNC}$ \\
\hline M-03 & Polybutylene terephthalate (PBT), GE Valox 357 & 76.2 & $\mathrm{DNC}$ \\
\hline M-04 & Chlorotrifluoroethylene (CTFE), Neoflon M-300 & 127 & $\mathrm{DNC}$ \\
\hline M-05 & $\begin{array}{l}\text { Crystalline polyvinylfluoride w/white pigment (PVF), } \\
\text { White Tedlar TWH10BS3 }\end{array}$ & 50.8 & $\mathrm{DNC}$ \\
\hline M-07 & Perfluoroalkoxy (PFA), Teflon PFA 500 LP & 127 & $\mathrm{DNC}$ \\
\hline M-08 & Tetrafluoroethylene-ethylene (ETFE), Tefzel ZM & 76.2 & 4.26 \\
\hline${ }^{\mathrm{a}} \mathrm{M}-11$ & Fluorinated ethylene propylene (FEP), Teflon FEP & 50.8 & 2.09 \\
\hline M-13 & Ethylene-chlorotrifluoroethylene (ECTFE), Halar 300 & 76.2 & $\mathrm{DNC}$ \\
\hline M-14 & Polyimide BPDA (Upilex-S) (PI), Upilex-S 25S & 25.4 & $\mathrm{DNC}$ \\
\hline M-16 & Polyamide 6 (PA 6), Nylon 6 & 50.8 & $\mathrm{DNC}$ \\
\hline M-17 & Polyamide 66 (PA 66), Nylon 66 & 50.8 & 5.61 \\
\hline M-18 & Polyacrylonitrile (PAN), Barex 210 & 50.8 & 8.60 \\
\hline M-19 & Polybenzimidazole (PBI), Celazole PBI 22 & 50.8 & $\mathrm{DNC}$ \\
\hline M-21 & $\begin{array}{l}\text { Poly(p-phenylene-2 6-benzobisoxazole) (PBO), } \\
\text { Balanced Biaxial film }\end{array}$ & 25.4 & $\mathrm{DNC}$ \\
\hline M-23 & Polyetheretherketone (PEEK), Victrex PEEK 450 & 76.2 & 9.92 \\
\hline M-24 & Polyethylene terephthalate (PET), Mylar A-200 & 50.8 & 0.76 \\
\hline M-25 & Polyimide (CP1) (PI), CP1 & 76.2 & 1.51 \\
\hline Q-2 & Tetrafluoroethylene-ethylene (ETFE), Tefzel 500 LZ & 127 & 6.91 \\
\hline $\mathrm{T}-1$ & Polymethyl methacrylate (PMMA), Plexiglas & 50.8 & 0.40 \\
\hline $\mathrm{T}-4$ & Polysulphone (PSU), Thermolux P1700 & 50.8 & DNC \\
\hline $\mathrm{T}-5$ & Polyurethane (PU), Duraflex PS S010 & 50.8 & DNC \\
\hline T-6 & Polyvinylidene fluoride (PVDF), Kynar 740 & 76.2 & 2.16 \\
\hline $\mathrm{T}-7$ & Polyvinyl fluoride (PVF), Tedlar TTR10SG3 (clear) & 25.4 & 0.38 \\
\hline $\mathrm{U}-1$ & Polyetherimide (PEI), Utem 1000 & 254 & DNC \\
\hline $\mathrm{U}-2$ & Amorphous Fluoropolymer (AF), Teflon AF 1601 & 50.8 & 1.45 \\
\hline $\mathrm{U}-3$ & Polyimide PMDA (PI), Kapton E & 50.8 & 1.28 \\
\hline $\mathrm{U}-5$ & Ultra High Molecular Weight Polyethylene (UHMWPE) & 254 & $\mathrm{DNC}$ \\
\hline $\mathrm{U}-7$ & Polyvinyl chloride (PVC), Clear-Lay Rigid PVC & 127 & DNC \\
\hline $\mathrm{V}-1$ & $\begin{array}{l}\text { Tetrafluoroethylene hexafluoro-propylene vinylidene } \\
\text { fluoride (THV), Clariflex }\end{array}$ & 254 & 25.72 \\
\hline${ }^{b} \mathrm{~V}-2$ & $\begin{array}{l}\text { Expanded polytetrafluoroethylene (ePTFE) } \\
\text { (ISS cable material) }\end{array}$ & 228.6 & $\mathrm{DNC}$ \\
\hline $\mathrm{V}-3$ & $\begin{array}{l}\text { Polytetrafluoroethylene (PTFE), PTFE T-100 Virgin } \\
\text { Skived Sintered Film }\end{array}$ & 76.2 & 5.03 \\
\hline $\mathrm{V}-4$ & Polyimide (PI), Kapton $100 \mathrm{CB}$ & 127 & $\mathrm{DNC}$ \\
\hline $\mathrm{V}-5$ & Poly Arylene Benzimidazole (TOR) & 38.1 & 0.46 \\
\hline V-6 & Poly Arylene Benzimidazole (COR) & 38.1 & 0.70 \\
\hline $\mathrm{V}-7$ & Polysulfone (PSO) & 50.8 & $\mathrm{DNC}$ \\
\hline $\mathrm{X}-1$ & Polyethersulfone (PES) & 76.2 & $\mathrm{DNC}$ \\
\hline $\mathrm{X}-2$ & Polymethylpentent (PMP) & 50.8 & 0.40 \\
\hline
\end{tabular}

${ }^{a}$ FEP had cracks in the surface before bend-testing

$\mathrm{b}$ ePTFE is bright white and cracks may be hard to see 


\section{Summary and Conclusions}

A study was conducted to characterize the embrittlement of thin film polymers after exposure to the space environment. In these investigations a bend test procedure was used to characterize the embrittlement of 37 different polymers that were exposed to LEO aboard the ISS for 13 months in a nadir-facing orientation as part of the MISSE 5 PEACE polymers experiment. Using mandrels of different diameters combined with optical microscopy, the strain necessary to induce surface cracking was determined for flight samples and compared with that of pristine samples. While none of the pristine materials cracked at the highest strain available, 18 of the 37 flight samples ( 49 percent) experienced embrittlement, shown by surface-tensile-induced cracking, after just 13 months of exposure in LEO. Two of the polymers, PMMA and PMP, had cracked while on-orbit and were so brittle that they fractured when bend-tested with the largest mandrel. These results indicate that many thin film polymers are susceptible to embrittlement in the LEO space environment, even after low solar and particle radiation exposures. Therefore, even "minimal" amounts of radiation exposure must not be overlooked when designing spacecraft components based on expected mechanical properties.

\section{References}

1. Dever, J.A., Banks, B.A., de Groh, K.K., Miller, S.K., Degradation of Spacecraft Materials (Chapter 23), in Handbook of Environmental Degradation of Materials, Myer Kutz (editor), William Andrew Publishing, pp. 465-501, 2005.

2. Townsend, J.A., Hansen, P.A., Dever, J.A., de Groh, K.K., Banks, B.A., Wang, L. and He, C., "Hubble Space Telescope Metallized Teflon FEP Thermal Control Materials: On-Orbit Degradation and Post-Retrieval Analysis," Special Issue: High Perform. Polym 11 (1999) 81-99.

3. de Groh, K.K., Banks, B.A., Dever, J.A., Jaworske, K.J., Miller, S.K., Sechkar, E.A. and Panko, S.R., "NASA Glenn Research Center's Materials International Space Station Experiments (MISSE 1-7)," Proceedings of the International Symposium on "SM/MPAC\&SEED Experiment," Tsukuba, Japan, March 10-11, 2008, JAXA-SP-08-015E, March 2009, pp. 91-119; also NASA/TM-2008-215482, December 2008.

4. Miller, S.K.R. and Dever, J.A., "Materials International Space Station Experiment 5 Polymer Film Thermal Control Experiment," Journal of Spacecraft and Rockets, Vol. 48, No. 2, March-April 2011.

5. Walters, R.J. et al. "Forward Technology Solar Cell Experiment First On-Orbit Data," 19th Space Photovoltaic Research and Technology Conference, Brookpark, Ohio, September 20-22, 2005, NASA/CP — 2007-214494. 



\begin{tabular}{|c|c|c|}
\hline \multicolumn{2}{|c|}{ REPORT DOCUMENTATION PAGE } & $\begin{array}{l}\text { Form Approved } \\
\text { OMB No. 0704-0188 }\end{array}$ \\
\hline \multicolumn{3}{|c|}{$\begin{array}{l}\text { The public reporting burden for this collection of information is estimated to average } 1 \text { hour per response, including the time for reviewing instructions, searching existing data sources, gathering and maintaining the } \\
\text { data needed, and completing and reviewing the collection of information. Send comments regarding this burden estimate or any other aspect of this collection of information, including suggestions for reducing this } \\
\text { burden, to Department of Defense, Washington Headquarters Services, Directorate for Information Operations and Reports (070404-018), , } 1215 \text { Jefferson Davis Highway, Suite } 1204, \text { Arlington, VA } 22202-4302 \text {. } \\
\text { Respondents should be aware that notwithstanding any other provision of law, no person shall be subject to any penalty for failing to comply with a collection of information if it does not display a currently valid OMB } \\
\text { control number. } \\
\text { PLEASE DO NOT RETURN YOUR FORM TO THE ABOVE ADDRESS. }\end{array}$} \\
\hline $\begin{array}{l}\text { 1. REPORT DATE (DD-MM-YYYY) } \\
01-09-2012\end{array}$ & $\begin{array}{l}\text { 2. REPORT TYPE } \\
\text { Technical Memorandum }\end{array}$ & 3. DATES COVERED (From - To) \\
\hline \multirow{3}{*}{\multicolumn{2}{|c|}{$\begin{array}{l}\text { 4. TITLE AND SUBTITLE } \\
\text { Embrittlement of MISSE } 5 \text { Polymers After } 13 \text { Months of Space Exposure }\end{array}$}} & 5a. CONTRACT NUMBER \\
\hline & & 5b. GRANT NUMBER \\
\hline & & 5c. PROGRAM ELEMENT NUMBER \\
\hline \multirow{3}{*}{\multicolumn{2}{|c|}{$\begin{array}{l}\text { 6. AUTHOR(S) } \\
\text { Guo, Aobo; Yi, Grace, T.; Ashmead, Claire, C.; Mitchell, Gianna, G.; de Groh, Kim, K.; } \\
\text { Banks, Bruce, A. }\end{array}$}} & 5d. PROJECT NUMBER \\
\hline & & 5e. TASK NUMBER \\
\hline & & $\begin{array}{l}\text { 5f. WORK UNIT NUMBER } \\
\text { WBS 904211.04.02.30.17 }\end{array}$ \\
\hline \multicolumn{2}{|c|}{$\begin{array}{l}\text { 7. PERFORMING ORGANIZATION NAME(S) AND ADDRESS(ES) } \\
\text { National Aeronautics and Space Administration } \\
\text { John H. Glenn Research Center at Lewis Field } \\
\text { Cleveland, Ohio 44135-3191 }\end{array}$} & $\begin{array}{l}\text { 8. PERFORMING ORGANIZATION } \\
\text { REPORT NUMBER } \\
\text { E-18322 }\end{array}$ \\
\hline \multirow{2}{*}{\multicolumn{2}{|c|}{$\begin{array}{l}\text { 9. SPONSORING/MONITORING AGENCY NAME(S) AND ADDRESS(ES) } \\
\text { National Aeronautics and Space Administration } \\
\text { Washington, DC 20546-0001 }\end{array}$}} & $\begin{array}{l}\text { 10. SPONSORING/MONITOR'S } \\
\text { ACRONYM(S) } \\
\text { NASA }\end{array}$ \\
\hline & & $\begin{array}{l}\text { 11. SPONSORING/MONITORING } \\
\text { REPORT NUMBER } \\
\text { NASA/TM-2012-217645 }\end{array}$ \\
\hline \multicolumn{3}{|c|}{$\begin{array}{l}\text { 12. DISTRIBUTIONIAVAILABILITY STATEMENT } \\
\text { Unclassified-Unlimited } \\
\text { Subject Categories: } 18 \text { and } 27 \\
\text { Available electronically at http://WWw.sti.nasa.gov } \\
\text { This publication is available from the NASA Center for AeroSpace Information, 443-757-5802 }\end{array}$} \\
\hline
\end{tabular}

\section{SUPPLEMENTARY NOTES}

\section{ABSTRACT}

Understanding space environment induced degradation of spacecraft materials is essential when designing durable and stable spacecraft components. As a result of space radiation, debris impacts, atomic oxygen interaction, and thermal cycling, the outer surfaces of space materials degrade when exposed to low Earth orbit (LEO). The objective of this study was to measure the embrittlement of 37 thin film polymers after LEO space exposure. The polymers were flown aboard the International Space Station and exposed to the LEO space environment as part of the Materials International Space Station Experiment 5 (MISSE 5). The samples were flown in a nadir-facing position for 13 months and were exposed to thermal cycling along with low doses of atomic oxygen, direct solar radiation and omnidirectional charged particle radiation. The samples were analyzed for space-induced embrittlement using a bend-test procedure in which the strain necessary to induce surface cracking was determined. Bend-testing was conducted using successively smaller mandrels to apply a surface strain to samples placed on a semi-suspended pliable platform. A pristine sample was also tested for each flight sample. Eighteen of the 37 flight samples experienced some degree of surface cracking during bend-testing, while none of the pristine samples experienced any degree of cracking. The results indicate that 49 percent of the MISSE 5 thin film polymers became embrittled in the space environment even though they were exposed to low doses ( 2.75 krad (Si) dose through $127 \mathrm{~mm}$ Kapton) of ionizing radiation.

\section{SUBJECT TERMS}

International Space Station (ISS); Spaceflight experiment; low Earth orbit (LEO); Space environment; Extraterrestrial radiation;

Environmental degradation; Polymer; Embrittlement

\begin{tabular}{|c|c|c|c|c|c|}
\hline \multicolumn{3}{|c|}{ 16. SECURITY CLASSIFICATION OF: } & \multirow{2}{*}{$\begin{array}{l}\text { 17. LIMITATION OF } \\
\text { ABSTRACT } \\
\text { UU }\end{array}$} & \multirow{2}{*}{$\begin{array}{l}\text { 18. NUMBER } \\
\text { OF } \\
\text { PAGES } \\
16\end{array}$} & \multirow{2}{*}{$\begin{array}{l}\text { 19a. NAME OF RESPONSIBLE PERSON } \\
\text { STI Help Desk (email:help@sti.nasa.gov) } \\
\text { 19b. TELEPHONE NUMBER (include area code) } \\
\text { 443-757-5802 }\end{array}$} \\
\hline $\begin{array}{l}\text { a. REPORT } \\
U\end{array}$ & $\begin{array}{l}\text { b. ABSTRACT } \\
\mathrm{U}\end{array}$ & $\begin{array}{l}\text { c. THIS } \\
\text { PAGE } \\
\text { U }\end{array}$ & & & \\
\hline
\end{tabular}



